Медведев С.С., Зайцева В.А.

\title{
Причины совершения несовершеннолетними преступлений
}

Кубанский государственный аграрный университет им. И. Т. Трубилина

(Россия, Краснодар)

doi: $10.18411 / 1 j-07-2021-90$

\section{Аннотация}

В данной статье проведен правовой анализ причин совершения несовершеннолетними преступлений. На сегодняшний день совершение преступлений несовершеннолетними является одной из самых актуальных проблем, ведь, именно, несовершеннолетние являются наиболее криминально пораженной категорией населения. Поэтому важно рассмотреть данную проблему, выявить причины совершения преступлений, а также предпринять меры по ее предупреждению. Рассуждая о причинах совершения несовершеннолетними преступлений, необходимо рассмотреть такую важную категорию как детерминанты преступности, которая представляет собой определенный комплекс социальных явлений, совокупность которых порождает совершение преступления. Для того, чтобы воздействовать на преступность, способствовать её минимизации необходимо выяснить, что же влечёт её развитие. Данная тема требует длительного осмысления.

Ключевые слова: криминология, несовершеннолетние, преступление, причины преступления.

\section{Abstract}

This article provides a legal analysis of the reasons for juvenile crimes. Today, the commission of crimes by minors is one of the most pressing problems, because, namely, minors are the most criminally affected category of the population. Therefore, it is important to consider this problem, identify the reasons for the commission of crimes, and take measures to prevent it. Arguing about the reasons for the commission of crimes by minors, it is necessary to consider such an important category as the determinants of crime, which is a certain complex of social phenomena, the totality of which gives rise to the commission of a crime. In order to influence crime, to contribute to its minimization, it is necessary to clarify what entails its development. This topic requires a long reflection.

Keywords: criminology, minors, crime, causes of crime.

На сегодняшний день совершение преступлений несовершеннолетними является одной из самых актуальных проблем, поскольку несовершеннолетние - это категория населения, наиболее подверженная криминальному воздействию. Поэтому важно рассмотреть эту проблему, выявить причины совершения преступлений и принять меры по их предотвращению.

Обсуждая причины совершения преступлений несовершеннолетними, необходимо учитывать такую важную категорию, как детерминанты преступности, представляющие собой определенный комплекс социальных явлений, совокупность которых порождает совершение преступления. Чтобы влиять на преступность, способствовать ее минимизации, необходимо выяснить, что влечет за собой ее развитие [1].

Основные определяющие факторы можно разделить на внутренние (личностные) и внешние (ситуативные). К личным факторам относятся: хулиганские мотивы, асоциальный образ жизни (употребление алкогольных напитков, наркотиков и токсичных веществ), правовой нигилизм, низкая юридическая грамотность и т. Д.

К внешним факторам относятся: рост безработицы, которая в основном отрицательно сказывается на несовершеннолетних, поскольку молодым людям трудно 
найти подходящую работу из-за отсутствия соответствующей квалификации и опыта работы; негативные факторы, влияющие на формирование личности несовершеннолетнего; негативное влияние СМИ и различных антисоциальных групп [2].

Экономическая нестабильность в обществе, которая приводит к низкому уровню жизни населения, а также ослабление инфраструктуры здравоохранения, образования и культуры, особенно негативно сказываются на несовершеннолетних. Они уязвимы, потому что их система ценностей еще не сформирована, а их психика еще не сформировалась по сравнению со взрослыми [3]. Из-за нехватки денег у молодежи они начинают удовлетворять свои потребности незаконными способами. Сокращение организации досуга (спортивного, творческого) также влияет на рост преступности, поскольку многие молодые люди не знают, что с собой делать.

Также важно научить молодых людей духовным и нравственным ценностям формирования правового сознания и предотвращения противоправного поведения. Деформация психической жизни несовершеннолетних позволяет средствам массовой информации вводить стандарты повседневного поведения, не соответствующие ценностным ориентациям нашего общества (мода на наркотики, алкоголь, жестокость и т. д.).

Социальная среда предлагает широкий спектр агрессивных и незаконных моделей поведения. Как и в случае с большинством социальных навыков, усвоение модели преступного поведения предполагает наблюдение за действиями других и закрепление последствий этих действий.

Семейное воспитание также играет важную роль в определении преступности среди несовершеннолетних. При отсутствии родительской любви или ее дефиците подросток замыкается в себе, чувствует себя одиноким и испытывает негативные переживания по этому поводу. Неудовлетворенность семейными отношениями с родителями компенсируется отношениями в неформальной группе сверстников. Такая группа обычно антисоциальна [4].

Наибольшим криминогенным потенциалом обладают семьи, в которых происходят постоянные конфликты, переходящие в ссоры между родителями, в избиения отцом или матерью ребенка. Оказавшись в столь травматической ситуации, дети вынуждены искать своеобразные средства самообороны - использовать обман и лицемерие [6]. Грубое обращение с детьми со стороны родителей приводит к гневу у детей, который впоследствии проявляется во взаимоотношениях со сверстниками в виде жестокости, а впоследствии и жестокости по отношению к взрослым.

Применение физического насилия, которое используют родители для «воспитания» своих детей, отрицательно сказывается на формировании личности подростка. Как правило, для родителей, использующих этот метод, характерны следующие отрицательные черты характера: жестокость, нервозность, несдержанность, агрессия, раздражительность.

Основной причиной развития психических расстройств [5] y несовершеннолетних правонарушителей являются неблагоприятные условия их семейного воспитания, выражающиеся, в том числе, в наличии у родителей различных психоневрологических заболеваний, алкоголизме и пьянстве, аморальности, жестокости в семьях.

Согласно проведенным исследованиям, люди, подвергшиеся насилию в детстве, чаще совершают преступления против личности (убийства, изнасилования, непристойные действия и т.д.).

Обобщая вышесказанное, следует отметить, что наличие причин, способствующих преступности несовершеннолетних, не означает, однако, неизбежности совершения преступления. Эти причины в некоторой степени поддаются регулированию и устранению. Изучение причин преступности раскрывает сущность 
этого социально негативного явления, объясняет его происхождение, демонстрирует, от чего зависит существование преступности, что способствует ее сохранению и что ей противопоставляет. Ценность таких знаний заключается в том, что они позволяют эффективно бороться с преступностью.

В связи с вышеизложенным могут быть предложены следующие меры противодействия преступности несовершеннолетних: стабилизация экономики, снижение безработицы, повышение материального благосостояния населения, поддержка малообеспеченных семей, разработка специальных программ защиты прав несовершеннолетних в семья, преодоление правового нигилизма, разработка мероприятий по повышению эффективности труда по профилактике и выявлению алкоголизма, наркомании, наркомании, а также фактов домашнего насилия в отношении несовершеннолетних. В свою очередь, Президент РФ Владимир Путин предложил новые меры поддержки семей с детьми, в частности, Владимир Путин поручил Правительству в срок до 1 июля 2021 года проработать и ввести целостную систему поддержки семей с детьми. Особое внимание будет уделено неполным семьям, где воспитанием детей занимается только один родитель. Что, на наш взгляд, является косвенной мерой для борьбы с преступлениями, совершенные несовершеннолетними.

$$
* * *
$$

1. Криминология: учебник / под ред. В.Н. Кудрявцева, В.Е. Эминова. 5-е изд., перераб. и доп. М.: 2015.-360 c.

2. Башкатов, Л. Д. Криминотеология / Л.Д. Башкатов. - М.: Юридический центр, 2017. - 954 с.

3. Антонян Ю. М. Портреты преступников / Ю.М. Антонян // Криминолого-психологический анализ. М. - 2019. - С. 147

4. Бельский А.И. Криминологическая характеристика личности несовершеннолетнего преступника / А.И. Бельский // Российский следователь. - 2019. — № 15. — С. 48-50.

5. Бухаров М.А. Профилактика правонарушений и преступлений несовершеннолетних через их патриотическое воспитание / М.А. Бухаров // Научный диалог: Юриспруденция. - 2017. - С. 4-6

6. Валуйсков Н.В. Основания освобождения несовершеннолетнего от уголовной ответственности / Н.В. Валуйсков // Балтийский гуманитарный журнал. — 2017. — Т. 6. — № 4 (21). - С. 463-465.

Мелкумян Г.Г.

Роль обстановки совершения преступления для установления обстоятельств, подлежащих установлению, при предварительной проверке по делам об убийствах ФГБОУ ВПО «Кубанский государственный аграрный университет» (Россия, Краснодар)

doi: $10.18411 / 1 j-07-2021-91$

\section{Аннотация}

В статье раскрывается понятие обстановки совершения преступления при убийствах. Выявляется роль обстановки совершения преступления для установления обстоятельств, подлежащих установлению, при предварительной проверке по делам об убийствах. Проанализированы данные, свидетельствующие об обстановке совершения преступления по материалам уголовных дел, рассмотренных Октябрьским районным судом города Краснодара.

Ключевые слова: убийство, преступление, обстановка совершения преступления, место совершения преступления, время совершения преступления, обстоятельства, подлежащие установлению, при предварительной проверке по делам об убийствах, предварительная проверка, возбуждение уголовного дела.

\section{Abstract}

The article reveals the concept of the situation of committing a crime during murders. The role of the crime scene in establishing the circumstances to be established in the 